\title{
Eco-innovations in Network Relationships of Enterprises for a Low-carbon Economy
}

\author{
Katarzyna KOWALSKA * and Paulina SZYJA \\ Pedagogical University of Cracow, Cracow, Poland; katarzyna.kowalska@up.krakow.pl; paulinaszyja@wp.pl \\ * Correspondence: katarzyna.kowalska@up.krakow.pl
}

\begin{abstract}
Nowadays, taking into account economy, we are facing in the European Union transformation to a low-carbon economy. This process needs actions targeted for development of renewable energy sources, increasing energy efficiency, decreasing greenhouse emissions. Simultaneously, it is necessary to involve various entities in order to successfully carry out structural changes for implementation of low carbon economy. The paper presents the issue of networks between producers, which help them to adapt to the ongoing challenges related to a low-carbon economy and the development of innovations that are perceived as one of the most important elements of this process. In the latter case it is a particular type of innovation - eco-innovation. The scientific method is a case-study based analysis of good practices to present the issue of cooperation between enterprises which use eco-innovation to head towards a low-carbon economy. On the one hand, enterprises implement eco-innovations to adapt to the challenges of creating a low-carbon economy and on the other global companies wanting to support activities associated with combating climate change, seeking more and more highly specialized service providers who have innovative products, unique knowledge and skills necessary to perform complex objectives and expectations of the various groups of stakeholders.
\end{abstract}

Keywords: ecological innovations; low-carbon economy; enterprise networks; CSR

\section{JEL Classification: D29; L260; M140}

\section{Introduction}

Modern private enterprises are characterized by the ability to quickly adapt to changing external environment. It is an effect of the requirements of the free market economy, mechanisms of demand and supply conditioned by the needs and tastes of the customers and by access to production factors, the level of state involvement in the economy, scientific and technical progress, as well as of other challenges, such as ageing society, civilization diseases, or climate changes. All those are the challenges they have to face. In order to stay on the market and/or enter new markets, enterprises modernize and improve their products and services. They seek and implement innovations to increase the efficiency of various types of resources (people, material, finances, and information) at their disposal. In addition, they create new types of relationships between themselves which allow them to acquire knowledge and skills and to cooperate to increase the scale of operations, as well as to meet legal regulations and customers' needs, especially in the context of growing importance of care for the natural environment. Responsible business orientation, preceded by the awareness of today's and future realities of competition, mobilize to look for innovative solutions in business, new ways of operating which can improve the company's image on the market and often reduce the costs of its operations. In turn, these solutions (innovations), publicized and positively verified by the market, become a role model for other organizations.

Currently, particularly in the European Union, within the transformation to a low-carbon economy, activities related to adaptation to a new socio-economic development framework are being undertaken. The term of a low-carbon economy, popularized by the recent crisis of the real economy, is identified with the need for targeted actions:

- development of renewable energy sources,

- increasing energy efficiency,

- decreasing greenhouse emissions. 
Implementation of a low-carbon economy needs direct actions, which requires a number of changes in different areas:

- legal regulations,

- fiscal and financial instruments,

- adaptation of sectoral policies of the state (particularly those related to energy, transport and construction),

- changes on the labour market (a new type of workplace, new skills),

- technological changes focused on energy and raw materials efficiency,

- greater use of knowledge and electronic systems for communication, automation and robotisation,

- rational waste management.

Moreover, governments, enterprises and societies need to take an active role. In this paper, the authors consider the issue of enterprises which are making the necessary changes:

- in production processes, aimed at increasing the efficiency of energy and raw materials use, and reducing greenhouse gas emissions,

- in relation to services rendered to make them more environmentally friendly,

- in the product offer (in relation to ecological issues).

The development of a low-carbon economy is related to a transformation process whose one of the key elements are innovations of a special type: those associated with environmentally friendly solutions. In literature we can find a wide selection of terms related to this word "innovation". The genesis of the main issue of innovation is related to Joseph Schumpeter's theory of economic growth and a business cycle (Lemanowicz 2015: 63-64). A low-carbon economy is related to eco-innovation, environmental innovation (Szajczyk 2017), green innovation and other related terms. Practice of their creation and implementation needs knowledge, experience, financial expenses and entities willing to take the associated risk. Networks between enterprises are useful in this matter.

The paper presents the issue of networks between producers, which help them to adapt to the ongoing changes related to a low-carbon economy and the development of innovations that are perceived as one of the most important elements of this process. Within the issue of networks, the innovations include:

- cooperation in green-energy investments;

- cooperation in implementation of new green-solutions in production, services or products;

- teamwork in waste management;

- cooperation with local subjects to overcome environmental problems;

- collaboration in development of social innovation related to the environment; co-actions in market education.

We have to take entrepreneurs into consideration due to the fact that, as Z. Ács and W. Naudé have written, entrepreneurship is considered to be an important mechanism for economic development through employment, innovation, and welfare (Ács and Naudé 2012:6).

A wide selection of literature presents backgrounds of the theory of networks between enterprises and practices related to this issue. In practice, it is possible to distinguish corporate networks (facilities, branches belonging to a given organization) or cooperative networks. The latter, which are increasingly developing on the market, are the so-called vertical networks (connections of independent entities in a vertical arrangement, e.g. the principal, service contractor) or horizontal (connections of competing companies in the form of at least associations, purchasing groups or franchise networks) (Kowalska 2012).

More and more publications also show the entities' involvement in solutions aimed at creating a lowcarbon economy. They cooperate with others for obtaining such a goal. Further parts of this paper will include references to more literature. However, they present to a limited extent good practices in enterprise network systems for the development of eco-innovation and creating a low-carbon economy. This work is an attempt to fill this gap. 


\section{Methodology}

The scientific method is a case-study based analysis of good practices in the area of cooperation between enterprises which use innovation to head towards a low-carbon economy. The following problematic questions will be considered:

- why do enterprises cooperate to create a low-carbon economy?

- which of the functional parts of their activity is a basis for cooperation?

- why are innovation one of the elements of cooperation towards a low-carbon economy?

- what kind of innovation is implemented by enterprises in cooperation networks?

- what are the aims of this kind of innovation?

- what is the role of Corporate Social Responsibilities?

\section{Results}

\subsection{The issue of connection between innovation and low-carbon economy}

There is no one definition of a low-carbon economy on the level of the European Union. The document entitled "A Roadmap for moving to a competitive low carbon economy in 2050" mentions the transition, which means that the EU should prepare for reductions in its domestic emissions by $80 \%$ by 2050 compared to 1990. It is therefore necessary to take measures to reduce emissions, particularly of carbon dioxide, in the following sectors of the economy: energy, industry (especially heavy industry), transport, residential and services, and agriculture (EC 2011). In all those, the role of technological innovation is emphasised:

- energy: low-carbon technologies related to i.a. using renewable energy sources for energy generation;

- industry: i.a. more advanced resource and energy efficient industrial processes and equipment, increased recycling;

- transport: new engines, materials and design;

- residential and services: e.g. nearly zero energy buildings;

- agriculture: sustainable efficiency gains, efficient fertiliser use, bio-gasification of organic manure, improved manure management, better fodder, local diversification and commercialisation of production and improved livestock productivity, as well as maximising the benefits of extensive farming.

Detailed examples of technological innovations for a low-carbon economy are presented in the paper prepared by the experts of the Grantham Institute (Napp undated):

- aviation: biojet, hydrogen aircraft;

- industrial sector: carbon capture and storage, hydrogen in steelmaking, iron ore electrolysis;

- advanced biofuel supply: artificial photosynthesis for biofuels production, algae for bioethanol production;

- built environment: building materials alternative for steel and cement;

- negative emissions technologies: bioenergy with CCS, bio-char, ocean liming (OL), soda/lime process;

- energy storage: Thermal Cycle, Flywheels, Power-to-Gas, Lithium-Ion Battery, Redox Flow Battery, High Temperature, Sodium-based Batteries.

The specific kind of innovations mentioned above does not exhaust their catalogue. We can point out to those related to technology, organization, product/service, waste management, society, or market education. All of them, in terms of the issue of a low-carbon transition, should have ecological attributes (related to their living cycle) and/or introduce environmental friendly solutions (Figure 1.). 


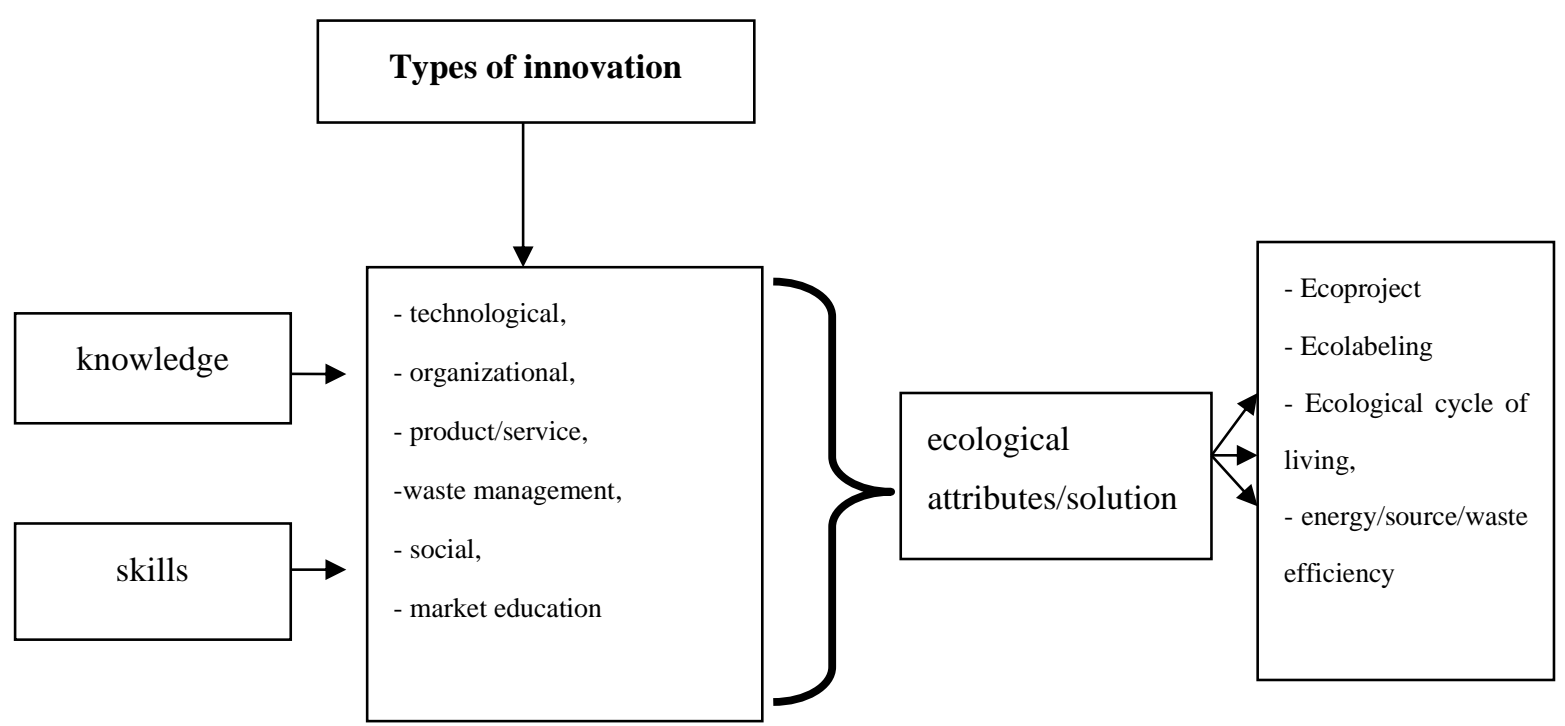

Figure 1. Innovation in transition to low-carbon economy.

Ecological features of innovation may be categorized by using more specific terminology. Innovations, related to the issue of a low-carbon economy, are characterized by the following terms:

- low-emission innovation,

- clean energy innovation and renewable energy innovation, energy efficiency innovation,

- climate-driven innovation,

- environmental innovation,

- eco-innovation,

- green innovation.

It should be emphasized that using the two last terms as synonyms is a misunderstanding. Ecoinnovation is the most precise and well-developed concept, whereas green innovation remains rather shallow (Schiedering et al. 2012). Green innovation is more strongly related to environmental benefits than to environmental aim. Such opinion is consistent with the definition by Gerstlberger et al. (2014) taken from Pujari (2006), who defines green innovations as new successful products, processes, or services integrating one or more positive environmental aspects (Murzyn and Szyja 2015). Here we can point out to the term of "environmental innovation" which is used interchangeably with "eco-innovation" (Ozusaglam 2012). As Ozusaglam (referencing to Kemp and Pearson 2007) emphasizes: most current definitions of eco-innovation are based on environmental performance rather than on environmental aim, since it is not the aim that is of interest, but whether there are positive environmental effects related to the innovation ("Measuring Eco-Innovation").

In other cases, the terms are explained as follows:

- low-emissions innovations: those allowing to reduce carbon dependency (OECD 2018);

- clean energy innovations: innovations related to generating energy from renewable energy sources; energy efficiency solutions facilitate i.a. energy storage (Vyas 2019);

- climate-driven innovation: innovation related to technological solutions aimed at reducing greenhouse gas emissions and mitigating the climate change (Nasdaq 2019).

We should also point out to the term of "sustainable innovation". Lorek points out that the key issue for making distinction between sustainable innovation and innovation in general is considering social and environmental factors. In order to develop an innovative solution in the sustainable category, it must have a positive impact on major environmental and social issues. Classic examples of sustainable innovations can be, for example, more efficient waste water treatment or the development of new types of dust reduction filters (Lorek 2018:34).

According to the terms mentioned above, the largest range should be assigned to sustainable innovation. For this paper, eco-innovation is more appropriate since we take into account the features 
of these innovations in the context of environmental impact. We should also point out that sustainable innovation is the widest embodied practical reflection of innovation in the context of the concept of sustainable development (Figure 2).

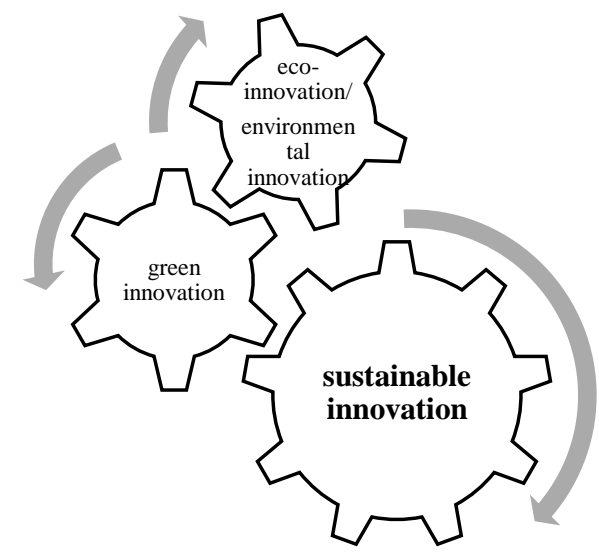

Figure 2. Sustainable innovation and its relation to eco-innovation and green innovation.

The role of innovation is strongly related to Europe 2020, the European Union's strategy, in which the following is highlighted:

Europe 2020 puts forward three mutually reinforcing priorities:

- Smart growth: developing an economy based on knowledge and innovation.

- Sustainable growth: promoting a more resource efficient, greener and more competitive economy.

- Inclusive growth: fostering a high-employment economy delivering social and territorial cohesion.

According to these goals, one of the flagship initiative of the EU is: "Innovation Union" to improve framework conditions and access to finance for research and innovation so as to ensure that innovative ideas can be turned into products and services that create growth and jobs (EU2010). This sentence states the main aim of creation and implementation of innovation. The link between innovation and a low-carbon economy is mentioned in the second development objective discussed in the document (smart growth).

The literature presents the issue of innovation in terms of the issue of a low-carbon economy, taking into consideration i.a.:

- operational aspects of different functional areas of businesses,

- materials used (Xu 2011),

- creation of new sustainable raw materials cycles (Moser and Feiel 2019),

- energy and energy efficiency ( Scheffran and Froese 2016),

- offered products and services (Das and Jharkharia),

- involved stakeholders: government, business, society (Ekins 2011),

- waste management (Mohareb and Hoornweg 2017),

- activities taken by governments, e.g. in China (Lewis 2012),

- good practices of SME (Baranova and Conway 2017).

\subsection{Eco-innovation and enterprise networks}

The issue of enterpise networks is presented in the literature, taking into account both theoretical aspects of their formation, operational aspects of functioning, as well as practical ones (Ricciardi 2016).

Enterprise networks are very important for transition into low-carbon economy in view of:

- the need to embark on the development of new products and/or services while addressing societal and environmental issues (Leite and Latifi 2016),

- development of new "green" skills (Conway et al. 2017),

- optimize operational processes related to production and services (f.ex. energy efficiency, water efficiency, waste management), 
- development of green public investments, and finally entrepreneurship is critical in promoting the necessary industrial growth and development (Hadjikhani et al. 2005).

This kind of networks are presented in literature by:

- innovation in SME's networks (Lindermann et al. 2009),

- product/service innovation,

- development of green supply chain network (Cao and Zhao 2013) - in mentioned strategy EUROPE 2020, is highlighted to strength the innovation chain, from 'blue sky' research to commercialization inter alia by public support (EU 2010).

The issue of enterprise networks is related with different types of them. For example Davide Knoke, according to considerations of Harrison White, writes: producers are embedded within "networks of continuing flows" of goods and services, procuring inputs from upstream suppliers and selling their outputs to downstream purchasers. Every market involves three distinct economic roles (suppliers, producers, buyers) (...), with two separate market interfaces (the upstream supplier-producer and downstream producer-buyer boundaries) (Konoke 2012: 60). Networks among producers in transition to low-carbon economy is needed because of cost of changes on operational level, investment in knowledge, development and implementation of innovations.

A modern enterprise, in order to maximize profits and develop over a long period of time, in conditions of such competition and still growing social expectations, has to meet the needs of various groups of stakeholders, minimize the broadly understood risk of business operations.

Business risk applies not only to the material but also to the non-material area in business (social capital, trust). Limiting the risk of traditionally understood supply chain (product quality, delivery time, etc.), as well as the growing importance of reputational risk, are two closely related areas, where an integral approach to risk management is the key and also the condition of the company's long-term success on the market.

Many companies (especially international ones) see an importance and real meaning of reputation in business, hence the visible involvement of these entities in corporate social responsibility (CSR).

Pioneering companies in this area, striving to create new business models based on CSR, are focused on achieving efficiency based on pro-social and environmental innovations (FOB 2011: 18). The CSR requirement in business becomes, in a way, an impulse for broadly understood innovations (table 1).

Table 1. Key differences between traditionally understood business and business based on CSR principles.

\begin{tabular}{|c|c|}
\hline Traditional approach & Innovation resulting from the concept of CSR \\
\hline $\begin{array}{l}\text { Focus on the company's economic } \\
\text { capital (narrow perspective). }\end{array}$ & $\begin{array}{c}\text { Perception of value of enterprise from a financial and } \\
\text { non-financial perspective (the role of intellectual } \\
\text { capital and social capital and trust). }\end{array}$ \\
\hline Focus on maximizing shareholder value. & Building value for all of the company's stakeholders. \\
\hline Focus on short-term goals. & Focus on short and long term goals and effects. \\
\hline $\begin{array}{l}\text { Disregarding social and environmental } \\
\text { costs or failure to report the impact. }\end{array}$ & $\begin{array}{l}\text { Measuring the company's impact on the environment } \\
\text { and systematic reporting. }\end{array}$ \\
\hline $\begin{array}{l}\text { Communication with the environment - } \\
\text { one way, asymmetrical. }\end{array}$ & $\begin{array}{c}\text { Communication with the environment - dialogue, } \\
\text { transparency. }\end{array}$ \\
\hline $\begin{array}{l}\text { Conducting business within the limits } \\
\text { set by law. }\end{array}$ & $\begin{array}{l}\text { Acceptance of voluntary, transnational commitments } \\
\text { in the form of codes of conduct, taking into account } \\
\text { social interests and environmental protection. }\end{array}$ \\
\hline
\end{tabular}

Source: FOB 2013: s. 8. 
Companies, especially the largest ones, compete in innovative solutions, such as innovative services or products. However, the requirements for innovative projects and products have changed over time, today innovation must simultaneously meet the needs of consumers and take into account and think about the good of society and the environment. Therefore, the assessment of a given project cannot be limited only to cost-effectiveness, but should take into consideration integrated efficiency, where social, economic and environmental effects of cooperation between enterprises in the whole supply chains are indicated.

The above realities and business requirements are part of the extensive cooperation processes of enterprises (their network). In practice, this cooperation may concern supply, sales, cooperation with companies which are known as a competition (Burt 2001: 110). These areas correspond to the terms: backward linkages, forward linkages and horizontal links.

Vertical connections of enterprises (supplier-recipient) are of key importance from the point of competition process and organization of supply. Due to the extensive supply chains and the growing popularity of outsourcing contracts, there is a great reputational risk at this level and the need of minimizing it. For example, the well-known Swedish clothing company H\&M cooperating with the network of over 700 independent suppliers in Europe and Asia (CENTRUMCSRCSR.PL Foundation 2013: 23) Such extended supply chains mean that the implementation of reputational risk reduction strategy is complicated and requires the client's consistent orientation to a CSR-based business.

In a vertical cooperation system, it is necessary to supervise the activities within one's own organization, as well as to control the services provided by external companies (Bielewicz and Meronek 2009: 146). Possible misuses of the supplier are often equated in public opinion with the practice of the principals.

A new way of operating of network organizations, based on CSR principles, and thus more efficient use of available resources, can become a source of innovative solutions in business by searching for and implementing innovative products or solutions (FOB 2013).

An example of the above can be the approach used by the American retail chain Wal-Mart Stores Inc., which, for image and cost reasons, has introduced a new, ecological approach to management. To implement this approach, called Sustainability 360, specific pro-ecological assumptions were adopted which resulted, among others significant retailer savings on the US market. For example, in order to increase the fleet efficiency of the above-mentioned network, fuel-saving technologies were installed in trucks (e.g. engine calibration improved), more aerodynamic shapes vehicles were introduced to the fleet, loading efficiency was improved, road routes were verified (FOB 2011: 57). According to available data, these activities allowed delivering 3\% more loads to stores in the USA while reducing the number of kilometers by 7\% (FOB 2011: 57). The above actions allowed for savings of USD 200 million in 2008 (FOB 2011: 57). Another activity of the corporation was the implementation of cooperation with suppliers to reduce the size of packaging (by 5\% to 2013 compared to 2008) of products offered in Wal-Mart stores (FOB 2011: 57). These activities were to bring specific savings in the form of lower fuel consumption during transport and reduction of $\mathrm{CO} 2$ emissions. Savings for Wal-Mart were then estimated at USD 3.4 billion (FOB 2011: 57).

The above example shows that innovation, understood as a new way of operating, more efficient use of resources, is caused by a strong need of creating a pro-social image, and its effect is both benefits for the surroundings of the organization (state of the environment, health of the local community), as well as savings and demand benefits, felt by the organization itself.

A similar ecological solution was used by the global leader in the logistics industry, Raben Group. The scope of corporation's activities includes contract logistics, storage, road transport, distribution and service of online stores (FOB 2016: 123).

As part of an innovative approach aimed at reducing negative environmental impact and reducing operating costs, improving the quality of life of the local community, as well as setting responsible trends in the industry, the company decided to change the way it manages the car fleet, its offices and warehouses, and offered regular educational programs addressed to its stakeholders (FOB 2016: 123). 
Raben Group operates, among others in Poland, Lithuania, Latvia, Germany and the Czech Republic. $85 \%$ of freight is transported in these countries by trucks, which means that significant amounts of fuel are burned and emissions are emitted (FOB 2016: 124).

Therefore, innovation concerned new solutions in managing key areas of the company's operations. In the scope of the car fleet, an eco-driving culture was introduced (reduction and monitoring of fuel consumption, employee training aimed at achieving ecological goals), and from 2012 the replacement of cars in the fleet with more ecological ones has begun; in the area of warehouses, solutions that have contributed to greater access to light in buildings and less resource consumption have been introduced (greater glazing in strategic locations of warehouses, installation of automatic light switches, energy-saving lighting, water start sensors) (FOB 2016: 124).

Another example of responsible management innovation, this time in the construction industry, is the approach taken by the MGPA group. The company manages, among others development and regeneration projects on the European and Asian market.

The product innovation for this company is office building the so-called the Rondo, the first building in Europe to have the DALI implemented, the system relating to lighting control (FOB 2016: 121). This building operates entirely based on renewable energy (FOB 2016; 121).

The building provides high ecological efficiency through a system that allows individual adjustment and control of each bulb and blinds; the use of energy-saving light bulbs, the latest ventilation and air conditioning systems, the use of devices with low water consumption (FOB 2016: 121). The latter solution reduced water consumption by 30\% in 2012 (FOB 2016: 121). On the other hand, cooperation and education of tenants resulted in greater waste segregation and a change in transport (from car to urban) in getting to work (63\% of tenants indicated such a change).

In turn, the Tesco chain of stores, representing the FMCG industry (the so-called high-speed industry, e.g. food, household chemicals, cigarettes), has started cooperation with DS. Smith, which resulted in the creation of new streams of selected waste suitable for recycling (FOB 2016). Redirecting a significant portion of waste from landfills to alternative waste treatment technologies means a reduction in operating costs for the company and creates the basis for building its image as a socially responsible organization.

Additionally Tesco declares that it undertakes all activities to ensure building lasting relationships with suppliers, using supplier audits carried out in accordance with recognized SMETA guidelines (FOB 2016).

The British network of Tesco, in cooperation with specialized suppliers, in addition to replacing the refrigerant R-404A with R-448A in commercial facilities, which in practice ensures a $68 \%$ reduction in direct carbon dioxide emissions (advanced refrigeration systems), invests in efficiency of energy and renewable energy sources; (Honeywell 2017: 2). Thanks to installed solar panels, the use of windmills and a ground heat exchanger, the company develops fully energy-efficient stores that use natural energy.

Network relationships between corporations and service contractors are an important part of the supply chain. An effective supply management chain is becoming an essential element for increasing the competitiveness and dynamics of development of international enterprises, which is why they are willing to transfer selected functions to their suppliers.

Such cooperation is often followed by the transfer of technology, eg. in the form of proprietary right transfer of know-how (eg. patents or licenses), product design and production processes and to determine their detailed specifications, counseling and assistance in adapting new technology. The literature emphasizes the role and importance of support providers by international corporations, which results in the development of innovation through implementation of various areas of cooperation between the parties discussed cooperation (eg. the introduction of a new product, information sharing).

On the other hand, global companies wanting to support, among others activities associated with combating climate change, seeking more and more highly specialized service providers who have innovative products, unique knowledge and skills necessary to perform complex objectives and expectations of the various groups of stakeholders. This cooperation is the foundation of change and solutions in line with market needs on a global scale. 


\section{Discussion}

Nowadays, in the face of a number of challenges, especially those that have a social and environmental dimension, enterprises are looking for and implementing various solutions to meet them. They take an active part in creating a low-carbon economy. They create new business models based on CSR and related with introducing different kinds of eco-innovation. Business cooperation processes are very helpful in this respect. Cooperation of companies concerns among others practices for increasing resource efficiency, operational efficiency, reducing product packaging, and processing waste. It should be also highlighted that companies are seeking highly specialized service providers with innovative environmental friendly products, services or operational solutions to perform complex objectives and expectations of the various groups of stakeholders.

Areas for further research and analysis:

- identification of factors determining the implementation of pro-ecological innovations in the SME sector operating in a network system and outside the network;

- identification of internal and external barriers in the implementation of green innovations in network relations and outside network enterprises;

- improving the business model as a source of value in business relations;

- transfer of pro-ecological technologies from transnational corporations to local enterprises of host countries.

\section{References}

Ács J. Zoltan, and Naudé Wim. 2012. Entrepreneurship, Stages of Development, and Industrialization. In Pathways to industrialization in the twenty-first century: new challenges and emerging paradigms. Oxford: Oxford University Press, pp. 373-392. https://doi.org/10.1093/acprof:oso/9780199667857.003.0014

Baranova Polina, and Conway Elaine. 2017. The Transition to a Low-Carbon Economy: An SME Perspective. The Low Carbon Economy. Understanding and Supporting a Sustainable Transition. In The Low Carbon Economy. Understanding and Supporting a Sustainable Transition. Cham: Palgrave Macmillan, pp. 87-115.

Bielewicz Antoni, and Meronek Hubert. 2009. 10 pitfalls of outsourcing projects. In: Harvard Business Review Polska. Burt Ronald. (2001). Structural Holes versus Network Closure as Social Capital. In Social Capital: Theory and Research. New York: Routledge. https://doi.org/10.4324/9781315129457-2.

Cao Cuizhen, and Zhao Guohao. 2013. Research on Network Optimization of Green Supply Chain: A Low-Carbon Economy Perspective. In LTLGB. Berlin: Springer, pp.465-471. https://doi.org/10.1007/978-3-642-34651-4

CentrumCSR.PL. 2013. Dirty profit. Available online: http://www.facingfinance.org/files/2014/02/Raport_Brudny-Zysk.pdf (accessed on 02/11/2019).

Conway Elaine, Paterson Fred, and Baranova Polina. 2017. The Transition to a Low-Carbon Economy: A Call for Collaborative Action Towards the 'New Normal'. In The Low Carbon Economy. Understanding and Supporting a Sustainable Transition. Cham: Palgrive Macmillan, pp.199-210. https://doi.org/10.1007/978-3-319-56753-2.

Das Chiranjit, and Jharkharia Sanjay. 2017. Adoption of Product and Process Eco-innovation for Developing Low Carbon Economy: A Rough Set Theory Based Analysis. In Climate Change Research at Universities. Cham: Springer, pp.497-517. https://doi.org/10.1007/978-3-319-58214-6_31

EC. 2010. Communication from the Commission. EUROPE 2020 A strategy for smart, sustainable and inclusive growth. Available online: https://eurlex.europa.eu/LexUriServ/LexUriServ.do?uri=COM:2010:2020:FIN:EN:PDF (accessed on 31 January 2020).

EC. 2011. Communication from the Commission to the European Parliament, the Council, the European Economic and Social Committee and the Committee of the Regions. Available online: http://www.europarl.europa.eu/meetdocs/2009_2014/documents/com/com_com(2011)0112_/com_com(2011 )0112_en.pdf (accessed on 31 January 2020).

Ekins Paul. 2011. System Innovation for Environmental Sustainability: Concepts, Policies and Political Economy. In. International Economics of Resource EfficiencyEco-Innovation Policies for a Green Economy. Heidelberg: Physica-Verlag HD, pp. 57-88.

FOB 2011. Measuring the effectiveness and social impact of CSR activities. Available online: http://odpowiedzialnybiznes.pl/wp-content/uploads/2012/12/Mierzenie-efektywnosci-dzialanCSR_FOB_2012.pdf (accessed on 18 November 2019). 
FOB. 2010. Expert article -Interview with Professor N. Craig Smith from INSEAD Social Innovation Center. Available online: http://odpowiedzialnybiznes.pl/artykuly/wywiad-z-profesorem-n-craigiem-smithem-zinsead-social-innovation-center/ (accessed on 2 October 2019).

FOB. 2016. Joint responsibility - The role of innovation. Available online: http://odpowiedzialnybiznes.pl/wpcontent/uploads/2013/03/FOB-rola-innowacji-176x250-2013-03-05-calosc-pojedyczne-strony.pdf (accessed on 5 November 2019).

Hadjikhani Amjad, Ghauri Pervez, and Johanson Jan. 2005. Introduction: Opportunity Development in Business Networks. In Managing Opportunity Development in Business Networks. London: Palgrave Macmillan, pp.1-24.

Honeywell. 2017. Tesco has started using the Solstice ${ }^{\circledR}$ N40 (R-448A) refrigerant as part of its carbon reduction plan. Available online: https:/www.honeywell-refrigerants.com/europe/wpcontent/uploads/2017/07/CaseStudy_Tesco_EN_2472017_Web .pdf (accessed on 5 December 2019).

Knoke David. 2012. Economic Networks. Cambridge: Economy Society.

Kowalska Katarzyna. 2012. The development of Polish retail chains as a way of limiting the market power of international commercial corporations. Warsaw: Difin.

Leite Emilene, and Latifi Mohammad. 2016. The Role of NGOs in Business Networks: Partnership in Innovation. In Extending the Business Network Approach. New Territories, New Technologies, New Terms. London: Palgrave Macmillan, pp.83-97.

Lemanowicz Marzena. 2015. Innovation in economic theory and the development of economic thought. Oeconomia: $14(4), 61-70$.

Lewis I. Joanna. 2012. Green Innovation in China. China's Wind Power Industry and the Global Transition to a LowCarbon Economy. New York: Columbia University Press.

Lindermann Nadine, Valcárcel Sylvia, Schaarschmidt Mario, and von Kortzfleisch Harald. 2009. SME 2.0: Roadmap towards Web 2.0-Based Open Innovation in SME-Networks - A Case Study Based Research Framework. In Information Systems - Creativity and Innovation in Small and Medium-Sized Enterprises. Berlin: Springer, Vol. 301, pp. 28-41.

Lorek Paweł. 2018. Sustainable innovation as an important factor of firm development. Ekonomia i Środowisko: 1 (64), 32-40.

Measuring Eco-Innovation Project co-funded by the European Commission within the Sixth Framework Programme (2002-2006).

Mohareb Eugene, and Hoornweg Daniel. 2017. Low-Carbon Waste Management. In: Creating Low Carbon Cities. Cham: Springer, pp.113-127. https://doi.org/10.1007/978-3-319-49730-3_11

Moser Peter, and Feiel Susanne. 2019. Raw Materials as a Driver of Economic Growth and Job Creation in the Transition to an Innovation-driven Low-carbon and Circular Economy. Berg Huettenmaenn Monatsh: 164(4), 156-158. https://doi.org/10.1007/s00501-019-0841-1

Murzyn Dorota, and Szyja Paulina. 2015. European Union efforts to create green growth through green innovation. Paper presented at the 11th International Conference of ASECU, Krakow, Poland, September 1011. Available online: http://asecu2015.fundacjauek.krakow.pl/proceedings/03.pdf (accessed on 31 January 2020).

Napp Tamaryn. A survey of key technological innovations for the low-carbon economy. Available online: http://www.oecd.org/env/cc/g20-climate/collapsecontents/Imperial-College-London-innovation-for-thelow-carbon-economy.pdf (accessed on 08 November 2019).

Nasdaq. 2019. Cultivating Innovation to Combat Climate Change. Available online: https://www.nasdaq.com/articles/cultivating-innovation-to-combat-climate-change-2019-10-09 (accessed on 12 December 2019).

OECD. 2018. Accelerating the development and diffusion of low-emissions innovations. Available online: http://www1.oecd.org/sd-

roundtable/papersandpublications/Accelerating\%20the \%20development $\% 20$ and $\% 20$ diffusion $\% 20$ of $\% 2010$ w-emissions\%20innovations.pdf (accessed on 12 December 2019).

Ozusaglam Serdal. 2012. Environmental innovation: a concise review of the literature. Vie E sciences de l'entreprise: 2(3), 15-38. https://doi.org/10.3917/vse.191.0015

Ricciardi Francesca. 2016. Innovation Processes in Business Networks. Wiesbaden: Springer.

Scheffran Jürgen, and Froese Rebecca. 2016. Enabling Environments for Sustainable Energy Transitions: The Diffusion of Technology, Innovation and Investment in Low-Carbon Societies. In Handbook on Sustainability Transition and Sustainable Peace. Cham: Springer, pp. 721-756. 
Szajczyk Marek. 2017. Process and Product innovations for the improvement of the state of the environment. In Innovation in management and engineering. Opole: Oficyna Wydawnicza PTZP. Available online: http://www.ptzp.org.pl/files/konferencje/kzz/artyk_pdf_2017/T1/t1_107.pdf (accessed on 9 November 2019).

Tundys Blanka. 2015. Measures of eco-innovation as an element of the green supply chain. Logistics: 2.

Vyas Kashyap. 2019. Energy Efficiency Innovations Changing the Game. Available online: https://interestingengineering.com/7-energy-efficiency-innovations-changing-the-game (accessed on 12 November .2019).

Xu Lejiang. 2011. Innovative Steels for Low Carbon Economy. In Advanced Steels. The Recent Scenario in Steel Science and Technology. Berlin: Springer, pp.9-14. https://doi.org/10.1007/978-3-642-17665-4_2 